\title{
DANGEROUS IMPLICATION OF TAKFIR
}

\author{
AGAM ROYANA \\ UIN MATARAM \\ agamroyana@uinmataram.ac.id
}

\begin{abstract}
Faith is a fundamental principle in religion. In Islam faith is an initial unitary step in undergoing worship which is called the pillars of faith. They are belief in Allah SWT, angels, scriptures, prophets, afterlife, andin the good and bad conditions which are had by His servants. However, in modernity and the treasures of Islam, Islam seems to be a late religion to be born. By reviving the strong desire in the golden era of the Salaf al-Shalih but with a textual understanding and regardless of the historical context. Some people are not aware that timeis changing, dynamic and developing, but Islam tends to be an exclusive, old-fashioned and not in line with modernity. A textual understanding emerges too much religious believers which had been reproached by previous believers. In fact, the Qur'an has presented testimony in its diction, reminded its people not to be too much, strict and radical. The phenomenon of overpracticing in religion cannot be underestimated, especially in this age of pluralism. Rigidity, and self-righteousness and even labeling other groups having different views as kafir or unbelievers really have negative effects, impacts and consequences. No wonder these dynamics make Moslems dichotomous and splitted, even easily played to fight against each other. This article tries to present how much the effect, impact and bad consequences on the label of kafir on otherMoslems. The researcher hopesto reduce people's carelessness on labelling other Moslems as kafir.
\end{abstract}

Keywords: Dangerous, Implication, Takfir

\section{A. Introduction}

In order to improve the quality of life standards, welfare, run development programs and maintain stability and security, many parties unite and work together mutually. It neglects differences in 
ethnicity, race, religion, culture and someof different backgrounds that hinder the process of unity. Many wars in the past did not become an obstacle in building togetherness and unity.

However, contradictory occurs in moslem society. Although the dictum of the Qur'an has clearly stated that these Moslems are the best and united people (ummatan wahidah), the bound of these people tends to be very easy to be broken, dichotomized, splitted and even played to fight against one another. In factmany people know that the unity of Moslems succeeded toconquer two great empires, they were Rome and Persia. Within 80 years, Moslems were able to conquer the Romans territory for 8 centuries. ${ }^{1}$ History records and tells their success, and great contributionin the development of civilization, which was gained by unity of Moslems.

One of the factors which weaken the unity among the people is the takfir or kafir labeling phenomenon. That is to label other people or groups as kafir. This is not a new phenomenon. It has already happened in early era of Islam, after the Siffin war (37 H / 658 $\mathrm{AD}$ ) on the west bank of the Euphrates river between the Caliph Ali bin AbiTalib's troops and Muawiyah's troops. At that time, the Khawarij² group emerged, which is considered the pioneer of the

${ }^{1}$ Muhammad Emarah, Fitnah al-Takfir, (Kairo, al-Majlis al-A'la li alSyu'un al-Islamiyyah, Wazarah al-Waqf), 61.

${ }^{2}$ The Khawarij is a group that is disappointed with the arbitration (tahkim) that Ali ibn AbiTalib has carried out. They considered all parties involved in the incident as kafir based on their interpretation on the Surah al-Maidah verse 44. In the development, this group was divided up to 20 groups. Their extreme view of takfir also develops, not only to those who do not apply the law based on 
first takfir movement in Islamic history. They categorized a Moslem who commits a major sin as a kafir or shirk. They even claimed Imam 'Ali as kafir because he refused to repent. It was because he had negotiated with his political opponent, Muawiyah. Imam 'Ali ibn Abi Talib, cousin and son-in-law of the Prophet Muhammad was considered to commit major sin and could be killed.

In the 2oth century the phenomenon of the takfiri group grew rapidly. This phenomenon not only occurs between individuals or groups, but has penetrated into Islamic activist groups and nation which are considered not to practice Allah's law. In addition, they label that country as nation of kafir and its leader as thagut that must be fought or even attacked. Several factors cause to the rise of this phenomenon recently. First, the classical history of Islam was full of takfir phenomena because of the conflict of interests, especially political interest. The second, understanding of the partial religious text is used as the legitimacy of their interests to fight other groups who do not agree with them. The three factors are economic gap, and political, social, and cultural aspects at the local, regional

and international levels. Many people who live with poverty and less education become an easy target for the spread of a culture of takfir and violence. ${ }^{3}$

\section{B. Definition of Takfir}

the Koran, but also to the moslem who commit big sins. See 'Abd al-Hhalim Mahhmud, al-Tafkiral-Falsafi fi al-Islam(Cairo, Dar al-Ma'rifah, 1989), 133.

${ }^{3}$ Muhhammad Syakir, Zhahirat al-Takfir, 'Awamil al-Nasy'at wa al-Thuruq al-Ilaj, al-Minhaj Lebanon Magazine, edition 56, 2009. 
Ibn Faris in said that Takfir is masdar from Kaffara which means covering something with something. Allah swt said in surah al-Hadid verse 20, farmers are kafir when they cover seeds with soil. 4 The definition of kafiralso includes rejecting the favors that have been given by showing in gratitude as stated by Allah swt in the surah Ibrahim (14) verse 7:

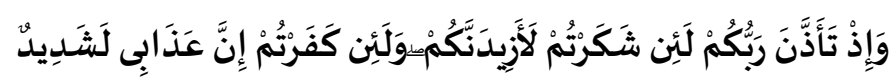

"And when your Lord made it known: If you are grateful, I would certainly give to you more, and if you are ungrateful, My chastisement is truly severe." 5

The highest level of kufr is closing the rights of Allah swt by denying the unity, teachings and messages of the prophets who were sent by Him. The most of the kufr term in the Qur'an are identified in religious meanings, namely not believing in the teachings brought by the Messenger. ${ }^{6} \mathrm{Al}$-Azhari linguist mentions that kufr is divided into four types according to their level. The first is Kufr 'Aqdi / Inkari, that is denying Allah as God both in belief and verbally. The second is Kufr al-Juhudi, which is acknowledging God in heart but not being practiced orally. This is what the Devil did, who does not obey God's command to prostrate to the prophet Adam. The third is Kufr al-Mu'anadah, that is accepting and acknowledging God by heart and verbally but reluctant to follow His provisions because of

4Ibn Faris, Mu'jam Maqayis al-Lughah, 5/156.

${ }^{5} \mathrm{QS}$. Ibrahim (14); 7,Al-Quran Al-Karim, (Translation of Kementerian Agama RI, 1971), 577.

${ }^{6} \mathrm{Al}-\mathrm{Raghib}$ al-Asfahani, al-Mufradat..., 2/561. 
ego, envy, envy, or hostility. This is what Abu Jahl did and Abu Talib did. Abu Talib said that the religion brought by Muhammad is the best on earth, if scorn of people didn't frighten me then surely I would follow it". The fourth is Kufr al-Nifaqi, which is a rejection from the heart and proclaiming by an oral confession. ${ }^{7}$

The antonym of Kufr is Iman. This word lexically comes from the word amina with finologies alif - mim and nun. According to Ibn Faris this word has two basic meanings, namely amanah (antonym of treason) and justification (al-Tashdiq). ${ }^{8}$ IbnMandzur said the word amina is grammatically used for four meanings, namely 1) Amanat, the opposite of treason; 2) Faith, the opposite of kufr; 3) Faith, in the sense of justifying; and 4) Safe, which means safe, the opposite of fear. 9

If the word Faith is defined as justifying (al-Tashdiq), then it implies in four forms of justification. First, verbal justification even though there is denial in his heart.Second, justification in heart, but denial in his mouth.Third, justification in heart and in oral. In this case, actions as the fruit of faith are not considered as the main element in faith, but are considered as complementary. Fourth, justifing in the heart, declaring it verbally, and manifesting it in actions (morals)..$^{10}$ Ibn Hajar added that the three elements of faith (heart, mouth, attitude) are a form of perfection of faith in the sight

${ }^{7}$ Al-Azhari, Tahdzib al-Lughah..., 3/363

${ }^{8}$ Ibn Faris, al-Maqayis..., 1/133.

9Ibn Mandzur, Lisan al-Arab..., 13/21.

${ }^{10}$ Ibn Hhajar al-Athqalani, Fathh al-Bari..., 1/9. 
of Allah. However, in the view of humans, a mere verbal statement can be considered as a believer and cannot be claimed as kafir, except someday he then does an act that invalidates his faith and shows his disbelief, such as worshiping sculpture. ${ }^{11}$

Most of scholars both from the Ahlussunnah, Shiites and $\mathrm{Mu}$ 'tazilites agree that faith has these three elements (belief, speech, and action). The difference is that ahlussunnah says that action is a condition for achieving the perfection of faith, while Muktazilah says that action is a condition for the validity of one's faith. The Murji'ah group argues that a person's faith is only related to the heart and mouth, has relation with deeds. For them, a person will still have the potential to be happy and safe in the afterlife without charity. Because the threat of the hell torment is only for those who do not believe (in heart and tongue). ${ }^{12}$

\section{Description of Faith}

The Messenger of Allah, through his words, has given a person a limit so that he is called a Moslem or has faith. That is:

${ }^{11}$ See Ibn Hhajar al-'Athqalani, Fathh al-Bari..., 1/11.

${ }^{12}$ Mukhlis Hanafi, Moderasi Islam, Menangkal Radikalisasi Berbasis Agama, (Jakarta; Ikatan Alumni al-Azhar dan PusatStudi Al-Quran PSQ 2013), Cet 1, 120. 
روي عن أبي هريرة فُبَّهُ أنه قال : قال رسول الله صلي الله عليه وسلم : "أمرت أن أقاتل الناس

حتي يقولوا لا إله إلا الله, فمن قال لا إله إلا الله عصيم مني ماله ونفسه إلا بحقه, وحسابه علي الله" ${ }^{13}$ (رواه البخاري)

"It was narrated from Abu Hurairahra.that the Messenger of Allah said: "I have been ordered to fight against people until they testify that there is no god but Allah. Whoever declares that there is no god but Allah, then his property and soul have been preserved from me, except in the right way (haq). And the reckoning is with Allah." (Narrated by Bukhari)

In addition, the words of the Messenger of Allah narrated by Imam al-Bukhari, which explains that whoever has said Syahadah and in his heart there is goodness then they have the right not to be eternal in hell. This is because their faith although it is only as big as a mustard seed or wheat. ${ }^{14}$

Several verses in the Qur'an also state that charity is something different and separate from Iman, it is the value and result of faith itself. As in the letter al-Baqarah verse 277, Allah swt says:

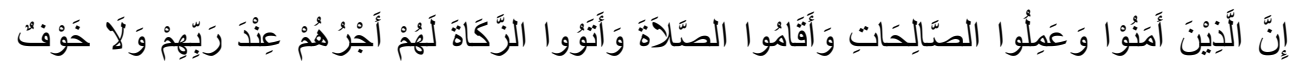

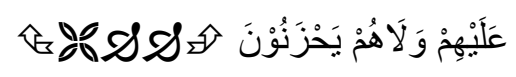

${ }^{13}$ Hadist narrated by Imam al-Bukhari in his book, chapter al-Iqtida' bi Sunan al-Rasul, no. 6741, and Imam Moslem in his book, chapter al-Amr bi Qital al-Nas, no. 31. Both are narrated by Abu Hurairah ra.

${ }^{14}$ Hadist narrated by Imam Bukhari in his book, chapter Shifat alJannahwa al-Nar, no. 6560 through Abu Sa'id al-Khudhrira. 
"Indeed thos who have faith, do righteous deeds, maintain the prayer and give the zakat, they shall have their reward near their Lord, and they will have no fear, nor will they grieve". ${ }^{15}$

In addition, there is also a verse that explains that the place of faith is in the heart. Allah swt says:

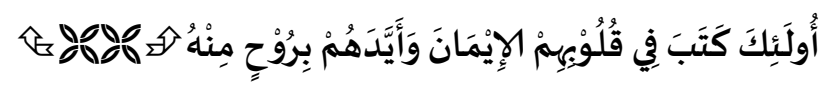

"...they are the ones who have planted faith in their hearts and strengthened them with help...". ${ }^{16}$

If charity (action) is part of Faith, then its place is certainly not in the heart. In addition, it is not enough for a person to be said as a believer if he only faith which justifies in his heart. Because one of the conditions for a person claimed to be believer physically is a verbal statement. Verbal statements are a condition for applying the law to someone as a believer, such as being invited to the mosque, praying, getting married and so on.

But the implicational question is"does one not need to do an act to prove his faith?" TheMurji'ah group argues that a person does not have an obligation to perform actions that have moral and religious values. According to Ahlussunnah, this opinion cannot be justified. Because faith that is formed as belief and is implemented

${ }^{15}$ QS. Al-Baqarah (2); 277, see al-Quran al-Karim, (translated by Kementerian Agama RI, 1971), 201.

${ }^{16}$ What is meant by help is inner will, cleanliness of heart, victory over enemies and others. QS. Al-Mujadilah (58); 22, see Al-Quran Al-Karim, (Translation of Kementerian Agama RI, 1971), 860. 
orally is a difference between a believer and an unbeliever. However, the form of faith that saves a person on the Day of Judgment is faith that has consequences and conditions outlined by the Qur'an and Sunnah. That is faith accompanied by good deeds in the form of obligatory (prayer, fasting, zakat and hajj) or morals.

\section{Kufr and Classification}

The majority of scholars, combine textual, reasoning and compromise various religious texts. They do not claim in Ahlu alQiblah as kafir as long as the sin they commit is not believed to be a provision of Allah and is not a major sin. If the act is done as a form of denial of Allah's sharia and the teachings of the Prophet, then they can be considered as kafir. But his kufr is not because of the sin he has committed, but because of his denial. In other cases, if there is a Moslem who denies the obligation to wear a head covering for a woman (hijab) because of her mistake in understanding the text and not because of his denial of the teachings of the Qur'an, then the she cannot be considered an kafir or apostate. ${ }^{17}$

The scholars classify kufr into two kinds which are related to belief and action; they are 'aqdi and 'amali. Kufr which is 'aqdiy causes a person to leave Islam and faith. Such as denying Allah, angels, holy books, messengers, the last day and the good and bad time from Him or what are called the pillars of Faith. In Surah alNisa Allah swt says:

${ }^{17}$ Huseyn al-Khasyin, al-Islamwa al-'Unf, Qira'ah fi Zhahirat al-Takfir, (Beirut; al-Markaz al-Thaqafi al-'Arabi, 2006), 23. 


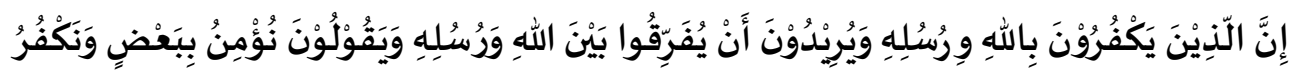

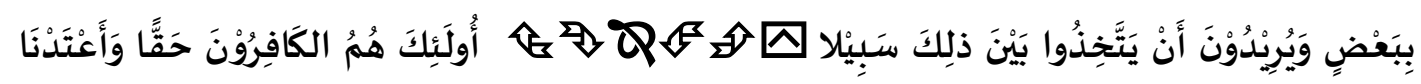

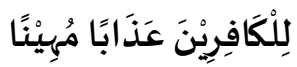

There are those who disbelieve in Allah and His Messengers and seek to differentiate between Allah and His Messengers, and say: 'We believe in some and deny others, and seek to strike a way between the two.' It is they, indeed they, who are, beyond all doubt, unbelievers; and for the unbelievers We have prepared a humiliating chastisement. ${ }^{18}$

However, kufr which is 'Amaliy and all forms and kinds of it, does not cause the moslem to leave Islam, but is only considered a as committing immorality/sin. Like denying the favor of Allah swt, as stated in the letter Ibrahim verse 7. In addition, Kufr 'Amali can also take the form of disobedience, disobeying orders or not staying away from prohibitions. As in the word of Allah swt:

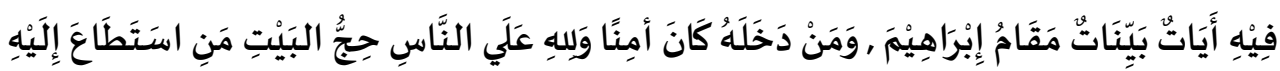

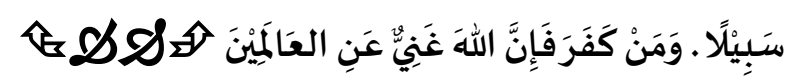

"In it are clear signs [such as] the standing place of Abraham. And whoever enters it [i.e., the Haram] shall be safe. And [due] to Allah from the people is a pilgrimage to the House - for whoever is able to

${ }^{18} \mathrm{QS} . \mathrm{Al}-\mathrm{Nisa}(4) ; 150-151$, See Al-Quran Al-Karim..., 397. 
find thereto a way. But whoever disbelieves [i.e., refuses] - then indeed, Allah is free from need of the worlds". ${ }^{19}$

In the same way, Ibn Qayyim distinguishes kufr into two kinds; al-Kufr al-Akbar (big kufr) and al-Kufr al-Ashghar (small kufr). He has argument that major kufr causes moslem kicked away from Islam and eternally in hell. While minor kufr causes the moslem to be threatened with the torment of hell but it is not eternal in it. The dictum regarding the existence of minor kufr is explained by several narration of the Prophet's tradition. As a narrated by Moslem from Abu Hurairah that he said: There are two things in my Ummah that can bring them to the kufr (minor), namely destroying kinship and mourning the dead (niyahah). ${ }^{20}$ Likewise, he said: "Do not return to kufr (minor) after my death, that is, some of you hit each other's necks, others (fight / kill each other). ${ }^{21}$

These various narrations explain that not all kufr predicates in the Qur'an and hadith are big kufr which causes someone to get out of Islam. Translating the two types of kufr without understanding of the true meaning can be fatal, and cause a person to easily claim other people or groups as kafir. For example, when reading and delivering the verse:

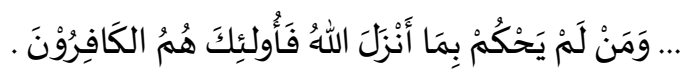

${ }^{19}$ QS. Ali 'Imran (3); 97, see al-Quran al-Karim..., 329

${ }^{20}$ Imam Moslem, Shahhih Moslem, babIthlaq Ism al-Kufr 'ala al-Tha'n fi alNasab, no. 100.

${ }^{21}$ Imam Bukhari, Shahih Bukhari, babal-Inshat li al-'Ulama', no. 118. 
"Whoever does not judge according to what Allah has revealed, then they are the disbelievers". ${ }^{22}$

There will be someone who interprets that anyone who does not use Allah's law in socializing in both moslem to moslem and moslem to non-moslem will be labeled a kafir and considered to be out of Islam. If this happens, there will be many Moslems with various educational backgrounds, professions, nations and across ages who will be disbelieved. If one persists in the labeling of kafir, then this has various stigmas as a consequence.

\section{E. Negative Impact of Takfir}

It is really bad thing if there are groups of Moslems who are too easy to claim other people or groups and even institutions as kafir just because of different views on matters of faith and fiqh. The Messenger of Allah gave a strict warning in this regard, he said:

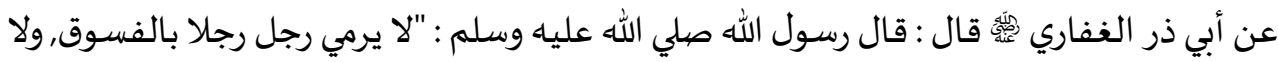

$$
\text { يرميه بالكفر, إلا ارتدت عليه إن لم يكن كذلك" (رواه البخاري) }
$$

"From Abu Dharr al-Ghifaryra.that the Messenger of Allah (saw) said: "One of you should not accuse others of being evil, or accuse others of disbelieve. If the allegations are not true, then the charges will be returned to him".23

${ }^{22}$ QS. Al-Maidah (5) 44, see al-Quran al-Karim..., .

${ }^{23}$ Imam Bukhari, Shahih Bukhari, chapter ma yunha min al-Sibab wa al$L a^{\prime} n$, no. 6045. 
In social life, labeling kafir to a person or group will have a negative impact, and even have postulative stigmatic consequences. Here are some of the stigmas that will arise as a result of the labeling of infidels:

\section{F. Eternity in Hell is a reward for the disbelievers}

The society of someone who is labeled as kafir will have a paradigm that that person will be tormented in hell eternally and no one will be able to help him. This is emphasized by Imam Subki that takfir is like telling the person that he will be in the hell and will last forever there. As stated by Allah swt:

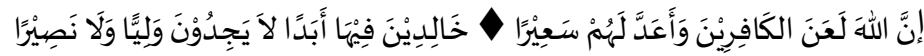

"Surely Allah condemns the disbelievers, and has prepared for them a blazing Fire. $O$ stays there for ever and ever-never will they find any protector or helper. ${ }^{24}$

It is undeniable that all of these will return to Allah's justice in the end. But it could be someone who commits an act that is considered bad and big sin by people, will be given blessing by Allah swt. Blessing which has implications toward forgiveness caused by acts of kindness that are not recognized by other people, as said by

${ }^{24} \mathrm{QS}$. Al-Ahhzab (33) 64-65, see al-Quran al-Karim..., 
the Messenger of Allah to the participants of the battle of $\operatorname{Badr}(a h l$ $a l-b a d r) .{ }^{25}$

\section{G. Unbelievers are punished as apostates, their blood and wealth are lawful}

Besides of being in hell eternally, people labeled as kafir are apostates. These are two stigmas from society. In Islamic law, people who apostate (leave from Islam) will get some consequences. It is lawful for his blood to be fought and killed, and his wealth is lawful to be seized. As the Messenger of Allah (saw) said: "Whoever changes his religion (apostates) then kills him!" ${ }^{26}$ Imam Shafi'i said: It was narrated by Abu Umamah ibn Sahl Hhanif from 'Uthman ibn'Affan that the Messenger of Allah said: "Moslem's blood is not lawfulto shed except with one of three, namely disbeliever after Faith, adultery after marriage, and killing someone". ${ }^{27}$

This decision is a law established by Allah and the Messenger of Allah, not ijtihad or human consensus. Why should apostates be killed? Because like a body, the individual in it is considered a cell that has a role. Likewise in Islamic society, every individual in it has a role,they have obligation and right to be protected. However, if someone apostates and leaving the Islamic order, it will be considered a dead cell. If these cells are allowed to live, they will become

${ }^{25}$ Rasulullah forgives Hathib ibn Abi Batha'ah at fathh Makkah. See Shahih Bukhari, chapter man lam yara ikfara man qala dzalika muta'awwilan, no. 4608. See Also Imam al-Hhakim, al-Mustadrak dzikr fadha'il al-Qaba'il, no. 7605.

${ }^{26}$ Imam Bukhari, Shahih Bukhari, chapter Qatl al-Murtadd wa alMurtaddah, no. 6922.

${ }^{27}$ See Imam Bukhari, Shahih Bukhari.., no. 6878, Imam Moslem..., no. 1676. 
embryonic tumors that will be harmful to the entire body. Therefore it must be isolated, quarantined, and the whole body will try to heal it and return it to the organs of the body. But if it cannot be cured, then the cell must be removed from the body.

The tahhkim mechanism is also carried out by the competent authorities, with a long procession and argumentation. It starts from discussions, mediation, persuasive approaches, and submission of evidence, granting requests for repentance (Istitabah), and even delaying executions. However, someone leaving Islam secretly, and hiding his beliefs and not showing anything that is against Islam, is not a proof that it is permissible to kill him. The matter is left to Allah and we should treat it like what witnessed together is.

\section{H. Conclusion}

In addition, social law is also applied to unbelievers from the aspect of marriage, inheritance, slaughter, not being bathed and praying when they die, and not being buried in Moslem graves. If this is really applied, then the person who is given label as kafir or unbeliever will be killed in character and morals, even without being physically killed.

Therefore, serious consideration is needed because negative impact caused by takfir is so huge. The scholars reminded us not to be easy to label a person or group or institution as kafir. Imam alGhazali emphasized that we should avoid labeling a Moslem as a kafir as much as possible. Because it is a big mistake to justifies 
bloodshed, property taking and rights depriving of someone who has prayed facing to Masjidil Haram and declares submission. In alIqtishad fi al-I'tiqad he explains that takfir mistakes has big consequences. Mistakes are like to a thousand disbelievers live easier than making mistakes which cause the killing of a Moslem. ${ }^{28}$

So Takfir can only be pinned to someone who expresses his disbelief openly. Making disbelief as faith and deny the two sentences of syahadah which are the main pillars of faith is considered to get out of Islam. With a different expression, Muhammad 'Abduh also reminded that one of the main teachings of Islam is to avoid Takfir. He emphasized that if someone's words lead to disbelief from a hundred directions but contain his faith from one direction, then faith will take precedence, and should not be immediately punished as unbelievers. ${ }^{29}$

\section{References}

'Imarah Muhammad, Fitnah al-Takfir, (Kairo: al-Majlis al-A'la li al-Syu'uhn al-Islamiyyah, Wazarah al-Waqf, 1993).

'Imarah, Muhammad, al-A'mal al-Kamilah l al-Imam Muhhammad 'Abduh, (Kairo; Dar al-Syuruq, 1993).

126.

${ }^{28} \mathrm{Al}-\mathrm{Ghazali}$, al-Iqtishad fi al-I'tiqad, (Kairo; Maktabah Syubaih, 1962), ${ }^{29} \mathrm{M}$ 'Imarah, al-A'mal al-Kamilah l al-Imam Muhhammad 'Abduh, (Kairo; Da $<$ r al-Syuruq, 1993), 3/302. 
al-Asfahani, Al-Raghib, Al-Mufradat di Gharib al-Qur'an, (Kairo; Dar al-Ma'rifah, 1997).

al-Azhari, Tahdzib al-Lughah.

al-Bukhari, Shahih al-Bukhari, (Kairo; Dar al-Fajr, 2001).

al-Bukhari, Shahih Bukhari, (Surabaya: Bait al-Ifkar Al Dauliah, 1997).

al-Ghazali, Abu Hamid, al-Iqtishad fi al-I'tiqad, (Kairo; MaktabahSyubaih, 1962).

al-Hakim, Imam, al-Mustadrak 'ala Shahhihhayn, 1994.

al-Khasyin, Huseyn, al-Islam wa al-'Unf, Qira'ah fi Zhahirat alTakfir, (Beirut; al-Markaz al-Thaqafi al-'Arabi, 2006).

al-Quran Al-Karim, TerjemahanKementerian Agama RI, 1971.

Hanafi, Mukhlis, Moderasi Islam, Menangkal Radikalisasi Berbasis Agama, Jakarta; Ikatan Alumni al-Azhar dan PusatStudi AlQuran PSQ, Cet 12013.

Ibn Hajar al-'Athqalani, Fathh al-Bari bi Syarh Shahhih al-Bukhari, (Kairo, Maktabah Tawfiqiyyah, 1996).

Ibn Mandzur, Lisan al-Arab, (Kairo, Dar al-Ma'rifah, 1999).

Ibn Faris, ibn Zakaria al-Qazwini al-Razi, Mu'jam Maqayis alLughah, (Kairo; Syirkah Maktabah Mushthafa, 1972). 
Mahhmud, 'Abd al-Halim, al-Tafkir al-Falsafi fi al-Islam, (Cairo, Dar al-Ma'rifah, 1989).

Muslim Imam, Shahih al-Moslem, (Kairo; Dar al-Hadith, 2003).

Syakir , Muhammad, Zhahirat al-Takfir, 'Awamil al-Nasy'at wa alThuruq al-Ilaj, Majalah al-Minhaj Lebanon, edisi 56, 2009.

Taher, Tarmizi, Berislam Secara Moderat, Jakarta; Grafindo, 2007.

Taher,Tarmizi, Agama Kemanusiaan Agama Masa Depan, (Jakarta; Grafindo, 2004).

Usman, Sjarif, Islam Membangun Peradaban Manusia Dengan Sempurna, (Jakarta; CV Jakarta, 1981). 